MA STEFAN GUŽVICA, PhD Candidate

University of Regensburg

Regensburg, Germany

guzvica.stefan@gmail.com

originalan naučni rad

UDK: 329.15.055(497.1:460)"1936/1939"

$355.426(460) " 1936 / 1939 "$

primljeno: 9. septembar 2018.

prihvaćeno: 21. novembar 2018.

https://doi.org/10.29362/ist20veka.2019.1.guz.53-74

\title{
THE SPANISH INQUISITION: FACTIONAL STRUGGLES AMONG THE YUGOSLAV INTERBRIGADISTAS
}

ABSTRACT: This article will examine the course of the factional struggle between Yugoslav communists that developed behind the frontlines of Spain in 1938 and investigate the involvement of foreign communists in their dispute. I will attempt to contextualize the struggles inside the Communist Party of Yugoslavia (KPJ) within broader power dynamics of the Comintern during the Great Purge, in order to gain a better understanding of both the KPJ and the Comintern as a whole in this period. The main organizer of the Yugoslav volunteers for the cause of the Spanish Republic, the KPJ, found itself in one of the most turbulent periods of its history at this particular time. In August 1937, its general secretary was arrested in Moscow and charged with espionage. The news of the arrest soon reached the volunteers in Spain, and many of them became engulfed in the emergent factional conflict, while struggling to make sense of the situation based on fragmentary information from abroad.

KEYWORDS: Communist Party of Yugoslavia, Spanish Civil War, Comintern, Josip Broz Tito, International Brigades

The outbreak of the Spanish Civil War in July 1936 coincided with the pinnacle of the career of the Yugoslav communist Milan Gorkić. Just twentynine days after the beginning of the conservative generals' revolt in Spain, on August 15, 1936, the Executive Committee of the Communist International (ECCI) confirmed the appointment of Gorkic as the general secretary of the Communist Party of Yugoslavia (KPJ). Although he had been the de facto leader of the KPJ since 1932, this decision decisively elevated him in status, with him no longer merely being a first among equals in a collective leadership, as was the case throughout most of his term. Moreover, his fiercest rivals and critics from the left, Vladimir Ćopić and Stjepan Cvijić, were sacked from the Pol- 
itburo. $^{1}$ In the coming months, they both went to Spain, keeping out of the way of Gorkić and intra-party struggles. At this point, the triumphant Gorkić had just over a year left to live. He was arrested on August 14, 1937, and shot on November 1 that same year. His rivals did not outlive him by much: Cvijić died in NKVD custody on August 10, 1938, ${ }^{2}$ while Ćopić was shot on April 19, 1939.

The arrest and execution of Gorkić was a turning point in the history of the KPJ. While hitherto the main targets of the Great Purge were members of the Yugoslav party who had opposed Stalin, from the summer of 1937, the NKVD turned against the KPJ leadership and other Yugoslav political émigrés. The Great Purge revived the factional struggles and created new ones, as the Yugoslav communists fought for both power and survival. During this chaotic period, three major factions competed for power, alongside several smaller groups and individuals. The first one was gathered around Josip Broz Tito, who would become the head of the "Temporary Leadership," and by the end of 1938, the acting general secretary of the party. The other two significant challengers were the "Parallel Center" in Paris, led by Ivo Marić and supported by his strong party organization in Dalmatia, and the "Wahhabis" of the imprisoned Petko Miletić, a hero of the Yugoslav workers' movement who enjoyed near-mythical status among the communists in the 1930s. Marić and the other members of the Parallel Center were expelled from the KPJ in the spring of 1939, while Miletić, by then also Marić's candidate for leadership, was arrested as a spy in Moscow in 1940, soon after his release from Yugoslav prison. By the time of the Fifth Land Conference of the KPJ in Zagreb in October 1940, Tito was the party's absolute leader.

The bitter dispute that preceded Tito's victory affected all levels of the party and all areas of its activity. The rump leadership suffered a legitimacy crisis and it struggled to enforce either authority or a coherent party line. Already in the fall of 1937, the disputes spread to the Yugoslav volunteers in the International Brigades. In this article, I intend to examine the little-known course of the factional struggle behind the frontlines in Spain and thus shed light on a significant blind spot in the history of the KPJ. I will demonstrate that, like in other cases, the struggle often revolved around grievances and disputes that either predated, or were unrelated to, the arrest of Gorkić. I will attempt to explain why the volunteers who sided with the Parallel Center against Tito's Temporary Leadership failed to garner significant support, and examine the aftermath of the struggle and its impact on subsequent individual destinies. In addition, I will attempt to contextualize the struggles inside the KPJ within broader power dynamics of the Comintern during the Great Purge, showing how other constituent parties were deeply involved, and sometimes divided on the issue of how to deal with the Yugoslavs.

\footnotetext{
${ }^{1}$ For a detailed account of the events of 1936, during which Cvijić and Ćopić attacked Gorkić, and his victory over them in the Comintern, see Ivan Očak, Gorkić: život, rad i pogibija (Zagreb: Globus, 1988), 241-251, and Nikita Bondarev, Misterija Tito: moskovske godine (Beograd: Čigoja štampa, 2013), 173-204.

2 Коста Николић, Мит о партизанском југословенству (Београд: Завод за уџбенике, 2015), 116.
} 


\section{The Re-Alignment: The Arrest of Gorkić and the Crisis of Legitimacy}

Yugoslavs made a significant contribution to the war effort of the Spanish Republic, with over 1700 volunteers fighting in the International Brigades. ${ }^{3}$ With so many fighters concentrated in a single country, the spillover of internal party disputes was virtually inevitable, especially considering that most of the fractioned party leadership was in Paris, a city through which a majority of Yugoslavs had to pass in order to reach the frontline. Nevertheless, few have written about Yugoslav factional struggles behind the lines. A notable exception is Vjeran Pavlaković, who wrote a chapter on internal political struggles in Spain for a recent English-language publication on the topic. ${ }^{4}$ Although his work is of the highest academic standard, the size of the publication did not allow for a broader inquiry into the subject. A new analysis of primary sources, both newlydiscovered and old, can help unravel the intriguing struggle that took place in Spain in 1937 and 1938.

According to memories of Yugoslav volunteers in Spain, the news of the arrest of Gorkic reached them already in the fall of $1937 .{ }^{5} \mathrm{He}$ had fallen out of favor due to a series of mass arrests in Yugoslavia, most notably the failure of the transport of about five hundred Yugoslav volunteers to Spain that spring, most of who were apprehended by the royal police in Montenegro. ${ }^{6}$ As a consequence, the Comintern began to suspect both Gorkić and other high ranking Yugoslav communists of being spies, labeling all those suspected of being close to him as gorkićevci. This accusation, although usually unfounded and never clearly defined other than as a support for Gorkić's policies, was to play a powerful role in the attempts to delegitimize one's political opponents after 1937.

Nothing was yet certain in late summer when the remainder of the party leadership was waiting in Paris, confused by the silence from the Comintern. Paris had become the new headquarters of the KPJ, both due to its proximity to Spain and because of the favorable climate created by the newly-elected Popular Front government, which enjoyed support from the communists. At the time of Gorkić's arrest, the main dramatis personae of the coming factional struggle were in Paris. Josip Broz Tito, a Politburo member and a close associate of

\footnotetext{
${ }^{3}$ The most significant and detailed work on the topic, which includes many eyewitness accounts, is Čedo Kapor's five-volume work Španija 1936-1939 (Beograd: Vojnoizdavački zavod, 1971). For a general overview of the Spanish Civil War, see Antony Beevor, The Battle for Spain: The Spanish Civil War 1936-1939 (London: Weidenfeld \& Nicolson, 2006).

${ }^{4}$ Vjeran Pavlaković, Yugoslav Volunteers in the Spanish Civil War (Beograd: Rosa Luxemburg Stiftung, 2016), 63-69.

${ }^{5}$ Stevan Belić, Na bojnim poljima Španije (Beograd: Narodna armija, 1970), 121. Belić says that this occurred around the time when Božidar Maslarić left the International Brigades to join the 45th Division, which took place in October 1937.

${ }^{6}$ For a detailed account of the fall of Gorkić, see: I. Očak, Gorkić, 257-262 and 285-289; Ubavka Vujošević, „Poslednja autobiografija Milana Gorkića, sekretara CK KPJ”, Istorija 20. veka, br. 1, (1997), 107-128; and Geoffrey Swain, Tito: A Biography (New York: I. B. Tauris, 2011), 18-19.
} 
Gorkić, had just returned from Yugoslavia, where he presided over the founding of the Communist Party of Croatia (KPH). Rodoljub Čolaković, another Politburo member, was given the task of running the party affairs in the absence of Gorkić (according to his own account, he would soon give this responsibility to Tito). ${ }^{7}$ Ivo Marić, a proletarian from Split and a long time trade-unionist, was the organizer of Yugoslav émigrés in France. Labud Kusovac, Marić's close associate, was a party intellectual with extensive intelligence links who had just returned from the Soviet Union, and who worked as the new head of the Yugoslav National Committee for Aid to Republican Spain. By the end of 1937, Tito and Čolaković would clash with Marić and Kusovac. Their dispute revolved primarily around the appointment of cadres, particularly in regards to Petko Miletic in the Sremska Mitrovica prison, the Dalmatian party leadership, and those individuals accused of being gorkićevci, such as Čolaković himself. Marić and Kusovac were against Čolaković, but supportive of Miletić and the Dalmatians. Tito's views were opposite of theirs on all counts.

In the months before the conflict between the groups erupted in December 1937, everybody was seemingly continuing with business as usual. Tito took his first cautious steps in regards to the Spanish situation less than a month after the arrest of Gorkić. In spite of the fact that nobody knew exactly what was going on, receiving no word from the general secretary or the Comintern was certainly a bad sign. Therefore, Tito was careful not to overstep his bounds and kept the Comintern informed throughout the entire process. ${ }^{8}$ In September 1937, he sent Colaković to Spain with a clear and modest set of tasks: accelerate the reassignment of Božidar Maslarić, meet Yugoslav volunteers at the front to better grasp the situation, and see how to help the volunteers away from the frontlines, primarily the sick and the wounded. ${ }^{9}$ Colaković had worked closely with Maslaric in the two-month period that followed, and oversaw his appointment as the new Central Committee (CC) representative in Spain, replacing the deceased Blagoje Parović, who was killed in battle. A schoolteacher from Osijek and a member of the KPJ since 1920, Maslarić would go on to become Tito's right-hand man among the Yugoslav volunteers and to play a crucial role in the factional struggle, defending Tito and his allies from accusations of ties to Gorkić.

As soon as the news of Gorkić's arrest began to spread, a search for spies and traitors ensued. Due to precautions about potential gorkićevci infesting the lines of the Yugoslav volunteers in this period, several people were sacked from their positions, including Vlajko Begovic the head of the intelligence service of the International Brigades, the Servicio de Inteligencia Militar (SIM). ${ }^{10}$ It is interesting to note here that a total of three Yugoslavs were heads

\footnotetext{
${ }^{7}$ Rodoljub Čolaković, Kazivanje o jednom pokolenju, tom III (Sarajevo: Svjetlost, 1972), 151.

${ }^{8}$ See Tito's letters to the Comintern in: Josip Broz Tito, Sabrana djela, tom III (Beograd: Komunist, 1981), 90-91, 102, 124-125.

${ }^{9}$ R. Čolaković, Kazivanje, tom III, 159.

10 Vladan Vukliš, Sjećanje na Španiju: Španski građanski rat u jugoslovenskoj istoriografiji $i$ memoaristici 1945-1991 (Banja Luka: Arhiv Republike Srpske, 2013), 25.
} 
of SIM. The first one was Roman Filipčev, ${ }^{11}$ who led SIM from "around December 1," 1936 until the end of October 1937. ${ }^{12}$ The second one was Begović, who was in charge of counter-intelligence from October 26, 1937 until February $6,1938 .{ }^{13}$ He shared this post with another Yugoslav, Karel Hatz, who kept the job even after Begović's sacking.

In spite of the measures against suspect Yugoslav volunteers in the International Brigades, Tito's Temporary Leadership itself seems to have kept Gorkić's suspected associates pretty close at least until early 1938. The very act of assigning Čolaković to responsible missions in Spain directly fed the distrust of Tito and his circle already harbored by people like Marić and Kusovac. Therefore, the question of party cadres in Spain further spoiled the relations between the Temporary Leadership and the Parallel Center. Tito most likely kept these individuals close to himself not because of their ties to Gorkić, but because they were already in an established position of authority, and he was not keen to disturb the status quo until receiving further information. Most probably, he was simply unaware of the severity of the charges that were being prepared against these individuals in Moscow.

\section{Maslarić versus the "Returnees"}

Following the return of Colaković to Paris in early December 1937, Maslarić remained the primary enforcer of Tito's faction in Spain and actively tried to bring all volunteers in line with the Temporary Leadership. In this, he was aided by the old Slovene communist Dragotin Gustinčič, who was in charge of mail and censorship in the International Brigade base in Albacete. Additionally, the group had foot soldiers in charge of gathering intelligence for the Temporary Leadership and writing reports to the Comintern and the Communist Party of Spain (PCE) denouncing the comrades who failed to follow the orders of the Temporary Leadership and its representative. ${ }^{14}$

At the end of 1937, the relations between communists had deteriorated considerably, in part also because of the news of the arrest of Gorkić. However, as I will show, all of the conflicts predated Gorkić's arrest. The main conflict was personal, starting as a feud between Gustinčič and Filipčev. Both arrived to Spain as political émigrés from the USSR, and were among the few Yugoslav

${ }^{11}$ Roman Filipčev (1895-1941), a craftsman from Vojvodina, was a participant in both the Russian and Hungarian revolutions and a founding member of the KPJ. He spent most of his career in the Soviet Union, teaching history at the Communist University of the National Minorities of the West (KUNMZ). He was killed in the Battle of Moscow in 1941.

12 Russian State Archives of Socio-Political History (Российский государственный архив социально-политической истории, RGASPI), 495-277-182, “В Отдел кадров Коминтерна, от Филипповича P.M.," August 9, 1939, 2-3.

${ }^{13}$ RGASPI, 495-277-17, “Биография - Владимир Стефанович,” February 10, 1938, 3.

${ }^{14}$ RGASPI, 545-6-1519, Въсов Васил, "Перечень вопросы касающись инстр. Ц.К. Роберта,“ September 1, 1938; Косталука Рамон, "Центральном комитету - Барцелона"; and RGASPI, 495-70-200a, Izjava o Španiji za CK KPJ, 26-27. 
communists in positions of great responsibility behind the lines, heading the censorship and the intelligence services, respectively. Before Parović's arrival to Spain in April 1937 as the CC representative, the two headed an ad hoc "Balkan Committee" in the International Brigades, and their dispute appears to have begun at the time. ${ }^{15}$ The details of it are largely obscure, although Filipčev blamed Gustinčič for losing his post as the head of SIM, ${ }^{16}$ and accused him of being a Slovene nationalist. ${ }^{17}$ It also remains unknown how Maslarić got involved in this dispute, but the rivalry between him and Filipčev would later be identified by the representatives of the PCE as the main source of discord among Yugoslav volunteers, with Gustinčič becoming less important. Moreover, it appears that Maslarić's post of party representative got him into conflict with many more individuals, as his 22-page long report written for the Comintern in August 1939 sheds light on his many personal conflicts with various commanders and fighters. ${ }^{18}$

The political problem above the personal dispute concerned a group of volunteers led by Filipčev who were, according to Maslarić and Tito, unwilling to fight. They were all Yugoslav political émigrés from the Soviet Union who questioned the authority of the party leadership and its representatives on the frontlines. Aside from refusing to go on the front, they would frequently make attempts to return to the USSR. Once Gorkić was arrested, their view seemed vindicated: they claimed that there is no more point in fighting, and hoped to return to Moscow, where they would wait for the Comintern to resolve the issue of the appointment of the new KPJ leadership. ${ }^{19}$ For this, they were dubbed the "Returnees" by Tito in his Comintern report from $1939 .{ }^{20}$ For lack of a better term, this is also what I will call their group.

After the news of Gorkić's arrest reached Spain, the Returnees' further justified their desire to leave the frontlines, at least in part, by the belief that gorkićevci, headed by Maslarić, might try to murder them in battle. ${ }^{21}$ This bred suspicion and conflict among the quarreling Yugoslav volunteers, further exacerbating the situation. It appears that the Returnees were the ones who first raised suspicions about the alleged murder of Parović, who preceded Maslarić as the party representative. The Comintern reported that the gossip spread

\footnotetext{
${ }^{15}$ RGASPI, 495-70-200a, 26.

${ }^{16}$ RGASPI, 495-70-200a, 39.

${ }^{17}$ RGASPI, 495-277-182, P.М. Филиппович, “Докладная записка о командировке в Испанию,“ August 9, 1938, 13.

${ }^{18}$ Archive of Yugoslavia (Arhiv Jugoslavije, AJ), Communist International - KPJ Section (790/1 KI), 1939/33, Božidar Maslarić, „Izveštaj o radu u Španiji”, August 31, 1939.

${ }^{19}$ AJ, 790/1 KI, 1939/33, 10-11.

${ }^{20}$ Pero Simić, Tito: svetac u magli (Beograd: Službeni list SCG, 2005), 104-105. I approach Simić's works with caution, given that his methodological approach was highly questionable and his interpretation of documents tendentious, misinformed and misleading. Nevertheless, Simić gathered and published an impressive amount of extremely useful primary source documents from the RGASPI, and these will be cited in my paper. All of the citations from Simić's book refer to published primary source documents unless otherwise noted.

${ }^{21}$ AJ, 790/1 KI, 1938/12, „Pismo br. 3 za Ota 5.III.1938.“ RGASPI, 495-70-200a, 16, 26, 39.
} 
through the ranks of fighters, and was further proliferated by Kusovac in Paris, ${ }^{22}$ who was linked to the Returnees. One of the most prominent Returnees, Nikola Kovačević-Chudnovski, was also subsequently Vladimir Dedijer's source for the controversial claim. ${ }^{23}$

In spite of their feigned concerns about sabotage by gorkićevci, the fact that the activity of the Returnees predated the arrest of Gorkic is corroborated by a letter Tito wrote to the KPJ representative to the Comintern in September 1937. In this letter, he complained about the Returnees for the first time, naming Chudnovski as the leader and "ideologue" of the group. ${ }^{24} \mathrm{~A}$ young communist reported to the party an incident from as early as February 1937, when he was sent by his commander to look for Dimitrije Stanisavljević - Furman, another Returnee, who failed to appear in the field of battle. He allegedly found Stanisavljević enjoying canned meat and ham eleven kilometers away from the frontline. ${ }^{25}$

The aforementioned trio of Filipčev, Chudnovski and Stanisavljevićc ${ }^{26}$ seems to have played a leading role among the Returnees. They were a very diverse group: Kovačević-Chudnovski was a former member of the left faction and a part of the temporary leadership of the KPJ in 1930; Stanisavljević was a former member of the right, while Filipčev does not appear to have been involved in earlier factional struggles. Their only common characteristics were that they had all come to Spain from the USSR, where they had spent many years, and that they were very deeply involved in early revolutionary activity in the 1920s. The group was never large in number: Maslarić named only ten of them in his 1939 report, ${ }^{27}$ and one of them, Vladimir Ćopić, was not actually a member of this mini-faction. The only other particularly notable individual

${ }^{22}$ RGASPI, 495-74-589, В. Громов, “Тов. Димитрову“, Мау 8, 1938, 2.

${ }^{23}$ Vladimir Dedijer, Novi prilozi za biografiju Josipa Broza Tita, tom II (Zagreb: Mladost, 1981), 319. Although not a single piece of evidence in support of this claim has been found, the conspiracy theory regarding Parović's alleged murder has captured the imagination of historians and the general public alike. Nikola Kovačević-Chudnovski (1894-1979) was a Bosnian social democrat who found himself in Russia as a prisoner of war and joined the Bolsheviks. He was a communist member of parliament during the brief period of KPJ's legality, and the fled to the USSR, where he lived until the breakout of the Spanish Civil War. After the fall of the Spanish Republic, he was interned in France. He eventually escaped from the camp and joined the French resistance, returning to Yugoslavia after the war. In 1948, he was arrested as a supporter of the Comintern Resolution and spent seven years in prison and on Goli otok.

${ }^{24}$ J. B. Tito, Sabrana djela, tom III, 94.

${ }^{25}$ In a colorful anecdote which deserves to be retold here in full, the young volunteer, Marko Spahić, was reportedly so angry that he pulled a gun on Stanisavljević, and was held back by another comrade. Stanisavljević then yelled at him, bragging of his achievements in the Comintern. To this, Spahić replied: "Even if Stalin himself allowed you to be here, you're still just a pussy to me." RGASPI, 495-70-200a, 25.

${ }^{26}$ The last member of the trio, Dimitrije Stanisavljević Krka (1899-1969) was another long-term émigré in the USSR, formerly close to Sima Marković. In Spain, he was the commander of the Dimitrov Battalion. Like Chudnovski, he sided with the Cominfrom Resolution and was sent to Goli otok. According to Ivo Banac, he was also "a functionary of the NKVD." Ivo Banac, With Stalin against Tito: Cominformist Splits in Yugoslav Communism (Ithaca, NY: Cornell University Press, 1988), 116.

${ }^{27}$ AJ, 790/1 KI, 1939/33, 11-14. 
among the Returnees was Mirko Marković, ${ }^{28}$ who would later be their connection to the Parallel Center. According to one report, a Bulgarian communist informed the $\mathrm{CC}$ representative that the Returnees were organizing meetings independently of their respective party organizations. ${ }^{29}$

\section{The Returnees and the Parallel Center}

The Returnees eventually developed the same doubts about the Temporary Leadership that Marić and Kusovac already harbored. The three preserved letters from Maslarić to Tito sent in early 1938 show this very clearly. Maslarić wrote to Tito that he is struggling to enforce the party line because the new leadership is generally seen by the volunteers as illegitimate. ${ }^{30}$ The CC of the PCE and the renegade Yugoslav volunteers were not convinced that the Temporary Leadership was cleared of gorkicevci or that it had any authority in the eyes of the Comintern, with Maslarić frequently accused of being a gorkićevac himself.

The Returnees began actively working together with the Parallel Center at some point. However, it remains unknown when and how the two groups came into contact. Tito's Temporary Leadership certainly struggled to find the connection. All that Maslaric could conclude in March 1938 is that one of them might have been in touch with Kusovac. ${ }^{31}$ This was repeated in a letter sent by the Comintern intelligence officer and a close ally of Tito, Josip Kopinič, to Georgi Dimitrov on August 4, 1938. ${ }^{32}$ It seems that all the information that Maslarić and the Temporary Leadership had about connections of the two groups was anecdotal. Hence, they were unable to make a strong case against them as factionalists. In the summer of 1938, after being attacked by his old friend Vladimir Ćopić as a factionalist and a gorkićevac, Čolaković assumed

\footnotetext{
${ }^{28}$ Mirko Marković (1907-1988), was one of the most colorful figures in the Yugoslav communist movement. A nephew of Lenin's friend Vukašin Marković, he organized armed uprisings with his uncle in Montenegro in the early 1920s in the hopes of sparking a communist revolution. After their failure, he immigrated to the Soviet Union and finished the KUNMZ. The Comintern then sent him to the United States, where he worked as an organizer of the Yugoslav diaspora. After returning to Moscow for a short time in 1936, he went to Spain, where he became the commander of the Washington Battalion. In Spain, he befriended Ernest Hemingway, who hosted him in Cuba after the fall of the Spanish Republic. After being allowed to re-enter the United States, he continued organizing the Yugoslav diaspora and mobilizing them for the war effort. In 1945, he returned to Yugoslavia and became the first dean of the University of Beograd's School of Economics. In 1948, he was arrested as a Cominformist and sent to Goli otok. After his release, he dedicated himself to scientific work and became one of the pioneers of cybernetics in Yugoslavia. Interestingly enough, in a fascinating memoir published posthumously, Marković does not mention anything about his disagreements with the KPJ in Spain. This is particularly curious since he was imprisoned by the Yugoslav regime as a Cominformist in 1948, and hence could have chosen to fashion himself as a prescient opponent of Tito a decade before the split, which some others chose to do.

${ }^{29}$ RGASPI, 495-70-200a, 27.

${ }^{30}$ AJ, 790/1 KI, 1938/12, ,Pismo br. 3 za Ota.“

${ }^{31}$ AJ, 790/1 KI, 1938/12, „Pismo br. 3 za Ota.“

${ }^{32}$ P. Simić, Tito: svetac u magli, 93.
} 
that he was slandered by Marić and Kusovac, but could not prove it. ${ }^{33}$ The historian Ivan Očak wrote that Ćopić met both Kusovac and Čolaković in Paris before he went to Moscow in 1938, in an attempt to hear out both sides of the conflict. ${ }^{34}$ Even if Čolaković had in fact been slandered by Kusovac, it is unlikely that Copić was seeking to support one or the other group in the dispute.

Subsequent evidence, however, shows that the two groups were indeed closely connected. After the war, the correspondence of Kusovac's ally Karel Hudomalj $^{35}$ resurfaced. He kept in touch with Mirko Marković, in early 1939, and informed him of what he considered to be the mistakes of the Temporary Leadership. ${ }^{36}$ Marković was a long-time opponent of Gorkić, ${ }^{37}$ and was thus watchful of the Temporary Leadership. Although the extent of his role remains unknown, he appears to have played a role of a double agent. He was certainly in contact with both the Temporary Leadership and Kusovac during his short stay in Paris in 1938. ${ }^{38}$ Marković began writing to Hudomalj in February 1939, expressing his dismay that the party had been taken over by "Trotskyists" and "other anti-party shitheads," and explicitly telling Hudomalj that he considered the Parallel Center to be the true representatives of the KPJ. ${ }^{39}$ Moreover, he stated that he was keeping in touch with Tito and that he could provide intelligence information on the Temporary Leadership, as Tito had trust in him. ${ }^{40}$ Another letter, sent from Kristina Kusovac to Hudomalj and dated April 13, 1939, in which she complains of "maslarićevci" arriving from Spain to the Soviet Union, ${ }^{41}$ shows that the Parallel Center was well-informed of the disagreements in Spain even after the fall of the Republic and their own marginalization in the KPJ.

${ }^{33}$ R. Čolaković, Kazivanje, tom III, 499.

${ }^{34}$ Ivan Očak, Vojnik revolucije: Život i rad Vladimira Ćopića (Zagreb: Spektar, 1980), 355.

${ }^{35}$ Karel Hudomalj-Oskar (1905-1944), was the former general secretary of SKOJ and a member of the KPJ since 1927. He was part of the party leadership alongside Chudnovski in the early 1930s. Hudomalj was one of the main opponents of Gorkić at the April Plenum, alongside Ćopić and Štefek Cvijić. He spent most of the 1930s in Paris, working with Yugoslav political émigrés. He fought in the Austrian resistance, organizing the antifascists along Popular Front lines and preparing collective resistance among Soviet prisoners of war who worked as forced laborers in Vienna. He was caught by the Gestapo and murdered in Mauthausen in 1944. His correspondence was probably uncovered by a Yugoslav communist or the French police after liberation and sent to Yugoslavia through the Consulate in Lyon. It was used as evidence against Labud and Kristina Kusovac in 1948, when they found themselves before the KPJ Cadres Commission. They were eventually sent to Goli otok. For details of the investigation and the couple's statements on factional activity with (among others) the International Brigade volunteers, see AJ, CC of the KPJ - Control and Statutary Commission (507/VII CK KPJ), Box 8/VIII - Labud i Kristina Kusovac.

${ }^{36}$ AJ, KPJ émigrés in France (507 CK KPJ - Emigracija), I/4, Letter of Marković to Hudomalj, February 18, 1939, 1.

${ }^{37}$ Milan Radanović, ,Jugoslovenski interbrigadisti pred Kontrolnom komisijom CK KPJ 19451949.“ (Bachelor's thesis, University of Beograd, 2016), 57.

${ }^{38}$ M. Radanović, „Jugoslovenski interbrigadisti pred Kontrolnom komisijom CK KPJ 19451949 “, 60.

${ }^{39}$ AJ, 507 CK KPJ - Emigracija, I/4, 1.

${ }^{40}$ Ibid.

${ }^{41}$ AJ, 507, CK KPJ - Emigracija, I/5, Letter of Krista Kusovac to Hudomalj, April 13, 1939, 2. 
Given their connection to the Parallel Center, the question of why the Returnees took such a relatively passive stance towards the issue of party leadership remains. They did not seem to have had their own candidate, and fully relied on their contacts in Paris. Unlike the Parallel Center itself, they never tried to organize or connect with other opponents of the Temporary Leadership in any way and their impact among the Yugoslavs in Spain was minor. There is no evidence that they ever tried to seriously agitate behind the lines and gain more followers. As already stated, Maslaric mentioned only ten of them by name and it seems that they did not have more than a few additional sympathizers. Only one of them ever dared to raise the issue of the party leadership while in Spain. That was Stanisavljević, who, according to Maslarić, insisted that the question of the new KPJ leadership be discussed among the volunteers, although the Comintern was strictly against such a proposal. ${ }^{42}$

In general, the behavior of the Returnees leaves the impression of vigilant Bolsheviks who were confident that the Comintern would eventually resolve the situation and make the right decision, although they nevertheless knowingly chose a side in the conflict. Their belief in the need for a preservation of party cadres for a future Yugoslav revolution was probably genuine, although it is easy to see how it would lead their opponents to think they are mere cowards. Moreover, at least one of them had a legitimate reason to stop fighting: Filipčev's health condition rapidly deteriorated in 1938 and he was eventually hospitalized in August of that year. ${ }^{43}$

\section{International Links in the International Brigades}

Although the Returnees did not threaten the Temporary Leadership through agitation among other volunteers, they did nevertheless pose a significant threat, mainly because of their connections with the Central Committee of the PCE and the Cadres Department of the International Brigades. The transnational networks developed by the Returnees in Spain were far more complex than anything that the Temporary Leadership had, making Maslarić's work extremely difficult. However, what these, as well as other networks, tell us about the inner workings of the Comintern and the International Brigades is as interesting as the Yugoslav factional struggle itself.

The sources related to the KPJ and its activity in Spain shed light on a semi-formal hierarchy of constituent parties of the Comintern. This hierarchy was never formally codified in official documents, although it affected practical day-to-day activities of the organization, and was constantly present in the correspondences of lower-ranking officials. In the case of the Balkan parties, the

\footnotetext{
${ }^{42}$ AJ, 790/1, KI, 1939/33, 12.

${ }^{43}$ RGASPI, 495-277-182, Филиппович, “Докладная записка о командировке в Испанию,“ 3 4. In May 1938, Filipčev was granted permission to leave Spain, but this did not happen until the evacuation of the International Brigades. RGASPI, 495-277-182, "Proposicion de la Comision de cuadros extranjeros, “ May 9, 1938.
} 
Bulgarian communists were on top, often overseeing the affairs of the KPJ and exercising influence over the Yugoslavs, while the Albanian communists, who did not even have a communist party until 1941, were under the jurisdiction of the KPJ. Although the dominance of Bulgarians in the Comintern after 1934 is well-known to scholarship, the impact this had on the KPJ has still not been thoroughly researched. ${ }^{44}$ Likewise, even though Yugoslav influence on Albanian communists from the outbreak of World War II has gained significant attention, almost no work has been done on the ties of Yugoslav and Albanian communists before 1941. The documents from Spain attest to a very complex and rather hierarchical relationship between the three parties.

Although Bulgarian predominance over the KPJ was somewhat "natural" given the position of Dimitrov and the fact that Bulgarians were taking up all the leading posts in the Comintern, it was by no means incidental. The Comintern intentionally gave them the tasks of overseeing the Yugoslavs, as was the case with the special commission formed to investigate Gorkic shortly before his arrest. ${ }^{45}$ In the same way that Bulgarians were heavily involved in special commissions pertaining to Yugoslav affairs, Gorkić, alongside Italian comrades, was responsible for overseeing the work of Albanian communists in the spring of $1937 .{ }^{46}$ The Albanian communists were permanently in a sort of a "joint custody" of the two larger parties.

The Albanians did not always look favorably at such an arrangement. They were opposed to Yugoslav dominance more than the Italian, and successfully fought for their inclusion into the Italian-speaking Garibaldi Battalion instead of the South Slavic one. ${ }^{47}$ Nevertheless, they remained closely tied to the KPJ, in particular through Gustinčič and Kusovac. Kusovac, as the head of the Committee for Aid to Republican Spain, was in charge of transporting both Yugoslav and Albanian fighters to Spain. The correspondence between him and Gustinčič shows that the pair had complete jurisdiction over Albanian communists. $^{48}$ The two kept in touch exclusively through the KPJ, as Gustinčič thwarted Kusovac's attempt to keep in contact with the International Brigades without the supervision of the Temporary Leadership. ${ }^{49}$ Gustinčič became a crucial figure in Yugoslav and Albanian affairs after Parović ensured that all

\footnotetext{
${ }^{44}$ Notable attempts at contributing to the topic are in Slavko Goldstein and Ivo Goldstein, Tito (Zagreb: Profil, 2015), 158, 162-163, and Jože Pirjevec, Tito i drugovi, tom I (Beograd: Laguna, 2013), 102-103.

45 RGASPI, 495-18-1211, "Protokoll (B) Nr. 167 zusammengestellt auf Grund fliegenden Abstimmung unter den Mitgliedern des Sekretariats des EKKI am 23. Juli 1937."

46 RGASPI, 495-18-1195, "Protokoll (B) Nr. 134 zusammengestellt auf Grund fliegenden Abstimmung unter den Mitgliedern des Sekretariats des EKKI am 15.IV.1937."

${ }^{47}$ Stephen Schwartz, "'Enverists' and 'Titoists' - Communism and Islam in Albania and Kosova, 1941-99: From the Partisan Movement of the Second World War to the Kosova Liberation War", Journal of Communist Studies and Transition Politics, 25, 1, (2009), 54.

48 The complete correspondence of Gustinčič is available in RGASPI, 545-2-80, and parts are in 545-6-1523.

${ }^{49}$ RGASPI, 545-2-80, Letter of Gustinčič to Kusovac, February 12, 1938.
} 
confidential correspondence goes through him for safety reasons. ${ }^{50}$ This shows a personalization of responsibility among the Yugoslav communists, since there was no formal party position that would have justified making Gustinčič a crucial intermediary in all party correspondence.

As a consequence of close ties between the Yugoslavs and Albanians in Spain, the fault lines of the KPJ factional struggle were mirrored among the Albanian communists. In fact, we cannot speak of two separate conflicts in the two groups: this was a single factional dispute which transcended national party lines. In this particular case, Kusovac's transnational links did him more harm than good. His closest associate among the Albanians was Llazar Fundo, ${ }^{51}$ the Albanian organizer in charge of transporting volunteers to Spain, who was, at the time, expelled from the Comintern for Trotskyism. Fundo was an Albanian national revolutionary-turned-communist, and was probably drawn to Kusovac, a former member of the KPJ left, due to a shared dislike for the Yugoslav state. Given that the left of the movement was generally seen as covertly Trotskyist, such a connection was enough to raise serious suspicions about Kusovac.

When it comes to the Albanians, Gustinčič was much more fortunate in terms of personal connections: he was a friend and a colleague of the communist writer Skënder Luarasi, who was the de facto highest ranking volunteer among the Albanians. ${ }^{52}$ The two worked in the censorship department together. Although Gustinčič was criticized for favoritism in his demeanor towards Luarasi, ${ }^{53}$ his sins were far lesser than Kusovac's. Through Luarasi, he could exercise influence over the Albanian communists which Kusovac could not through the ostracized Fundo. Letters from other Albanian volunteers corroborated the

${ }^{50}$ RGASPI, 545-2-80, Letter of Parović to Gustinčič, May 2, 1937.

${ }^{51}$ RGASPI, 545-6-1519, Otto (Walter), "Al Comité Central del Partido Comunista de España", August 5, 1938. This link was confirmed by Fundo himself during his trial in September 1944: Mithat Q. Begolli, Kryezinjtë e Gjakovës (New York: Association Libri, 2012), 306. Llazar Fundo (1899-1944) was one of the pioneers of communism in Albania. Born to a Vlach family from Moscopole, Fundo was originally a national revolutionary and a supporter the government of Fan Noli. After the fall of Noli in 1924, he moved to Vienna and soon began working for the Balkan Communist Federation. He was one of the initiators of the founding of the Communist Party of Albania (which would not happen until 1941) and a contributor to the periodical Balkan Federation. He was an organizer of Albanian volunteers for the International Brigades, but fell out with the Comintern because of the Moscow Trials, after which he was denounced as a Trotskyist. He was sentenced to death, but his sentence was allegedly commuted thanks to Georgi Dimitrov, and he returned to Albania. There, he joined the anti-communist and antifascist resistance. In 1944, he was captured and executed by the Albanian partisans.

52 As the Communist Party of Albania did not exist, there was no formal hierarchy. However, Luarasi was working at the censorship department in the International Brigades and was the editor of the Albanian-language magazine Vullnetari i Lirisë (Volunteer of Freedom). He was also in charge of reporting on Albanian volunteers to the Cadres Department of the International Brigades. RGASPI, 545-6-83, Skënder Luarasi, "Informe sobre los voluntaries Albaneses en Espana", November 3, 1938.

${ }^{53}$ RGASPI, 545-2-160, Willi Engels, "Rapport", undated. A report on Luarasi claims that he got the job in the censorship department at the personal request of Gustinčič. RGASPI, 545-6-85, "Caracteristicas. Skender Luarasi”, April 9, 1938. 
claim that there was a conflict between Luarasi and Fundo, which revolved around conflicting claims to authority over the Albanian volunteers. ${ }^{54}$ In his reports, Luarasi accused the "renegade" Fundo for causing desertion of several Albanian volunteers, most notably Petro Marko, who would become one of Albania's best-known modernist writers. ${ }^{55}$ These disputes, much like the Yugoslav ones, continued into the post-1945 period, as Marko was imprisoned by Hoxha's regime in the late 1940s.

Even though Kusovac and the Albanian faction he supported were both ultimately defeated, he had ties with far more reputable and influential personalities in the international movement, which were crucial for the enforcement of authority of the Parallel Center and of the Returnees, and which significantly hindered the efforts of Maslarić and Gustinčič as representatives of the Temporary Leadership. In Spain, all the leading Bulgarian communists sided with the Returnees, and some of them kept in touch with the Parallel Center. Maslaric named two members of the PCE Central Committee, under the pseudonyms Edo and Yanov, and the head of the Cadres Department, Georgi Dobrev-Zhelezov, as superiors who intentionally sabotaged his work. ${ }^{56}$ Edo was Edoardo D'Onofrio, an Italian communist who was a member of the PCE and served on the party's Foreigners Commission. ${ }^{57}$ Yanov was the Bulgarian communist Dimo Dichev, who was the head of the Slavic volunteers section at the Central Committee of the PCE. ${ }^{58}$ As I will later show, there is no evidence that such an assessment of Dichev is correct, although Zhelezov did apparently oppose Maslarić and Gustinčič ${ }^{59}$ and D'Onofrio actively helped Filipčev. Another Bulgarian communist, Anton Ivanov - Bogdanov, who was personally appointed by Dimitrov to go to Spain as a Comintern representative, ${ }^{60}$ met with Marić and Kusovac on his way to Albacete, but did not meet with Tito or anyone from his

${ }^{54}$ RGASPI, 545-6-83, Letter of I. Kurani to Loro Brahimi, February 5, 1938.

55 RGASPI, 545-6-83, Luarasi, "Informe sobre los voluntaries Albaneses en Espana”, 9. This report also accuses the "suspicious" Ali Kelmendi of sowing dissent among the volunteers. Kelmendi (1900-1939) was an early Albanian communist and a close comrade of Fundo since the 1920s. The two worked together in Paris on the transport of volunteers to Spain until Kelmendi's death of tuberculosis. In socialist Albania, he was hailed as the most important hero of the early communist movement, although this document indicates that not all was ideal in his attitude to the official line of the communist movement shortly before his death.

56 AJ, 790/1 KI, 1939/33, 15.

${ }^{57}$ Francesco M. Biscione, s.v. "D'ONOFRIO, Edoardo,” Dizionario Biografico degli Italiani, vol. 41 (Rome: Istituto dell'Enciclopedia Italiana, 1992). http://www.treccani.it/enciclopedia/ edoardo-d-onofrio_(Dizionario-Biografico)/ (accessed September 3, 2017).

58 Nissan Oren, Bulgarian Communism: The Road to Power 1934-1944 (New York: Columbia University Press, 1971), 134-35. I would like to thank John Kraljic for this insight.

59 Čolaković recalled a meeting between himself, Maslarić, and Zhelezov in the fall of 1937 at which Zhelezov criticized the KPJ for sending its finest cadres into battle, suggesting that Zhelezov was in touch with the Returnees very early on. R. Colaković, Kazivanje, tom III, 215217. Moreover, Zhelezov tried to sack Luarasi from his post and thus distance him from Gustinčič. RGASPI, 545-6-83, Letter of Gustinčič to Zhelezov, May 14, 1938.

60 Branko Lazitch and Milorad M. Drachkovitch, Biographical Dictionary of the Comintern (Stanford: The Hoover Institution Press, 1986), 195. 
inner circle. ${ }^{61}$ Upon his arrival to Spain, Bogdanov openly sided with the Returnees, and did not view Maslarić favorably, considering him a gorkićevac. ${ }^{62}$

Aside from the extremely sympathetic Bulgarian communists, Kusovac had the attention of the French communist leadership, most notably Maurice Tréand, who was a CC member, the head of the PCF cadre commission, in charge of the party's underground operations, and an ECCI operative in Western Europe. ${ }^{63}$ Tito frequently petitioned both PCF and PCE informing them of the perceived misdeeds of Kusovac. ${ }^{64} \mathrm{He}$ removed Kusovac from his post in the Committee for Aid to Republican Spain, but Kusovac continued his anti-Tito activity, remained in touch with the volunteers, and even petitioned Georgi Dimitrov directly thanks to the help of Tréand ${ }^{65}$ Kusovac and the Parallel Center remained in contact with the rebellious Yugoslavs and Albanians well into 1939. Although the Parallel Center eventually lost Tréand's trust, the Temporary Leadership was slow to gain it, ${ }^{66}$ further hindering their attempts at influencing the PCF.

Filipčev also used an extensive transnational network. He petitioned the PCE complaining about Maslarić's and Gustinčič's "sectarian-factional struggle" ${ }^{67}$ and even wrote directly to André Marty, the political commissar of the International Brigades. Although his letters to Marty have not been preserved, we know that he informed D'Onofrio of this. The correspondence between the two reveals that D'Onofrio was willingly assisting Filipčev both personally and politically, helping him receive a permit to leave Spain for medical treatment, and giving him advice on how to proceed against the representatives of the Temporary Leadership. ${ }^{68}$ Nevertheless, in his subsequent reports, D'Onofrio gave a measured assessment of his comrade, not fully taking his side in the dispute, and pointing out that Maslarić's accusations of Filipčev's unjustified refusal to work were not unfounded. ${ }^{69}$ Even so, all the other foreign supporters of the Returnees were far less measured in their judgment, and frequently showed open hostility to Maslarić. Therefore, the connections of Kusovac and the Returnees in effect prevented the Temporary Leadership from enforcing the party line in Spain, and resulted in two conferences which Maslarić saw as personal and political defeats.

${ }^{61}$ AJ, Memoirs' Collection (516 MG), Box 58, 2231/2, „Razgovor sa drugom Ivom Marićem“, 53, and R. Čolaković, Kazivanje o jednom pokoljenju, tom III, 434.

${ }^{62}$ RGASPI, 495-277-182, Филиппович, “Докладная записка о командировке в Испанию,“ 5.

${ }^{63}$ Ivo Banac (ed.), The Diary of Georgi Dimitrov 1933-1949 (New Haven: Yale University Press, 2003), 109.

${ }^{64}$ Josip Broz Tito, Sabrana djela, tom IV (Beograd: Komunist, 1981), 35, and RGASPI, 545-61519, Otto, “Al Comité Central del Partido Comunista de España", August 5, 1938.

${ }^{65}$ RGASPI, 495-74-589, “Cher camarade D.," letter of Legros (Tréand) to Dimitrov, April 20, 1938.

${ }^{66}$ As late as August 1939, Tréand refused to meet Tito, even though Tito had a mandate of the Comintern at this point. J. B. Tito, Sabrana djela, tom IV, 335.

${ }^{67}$ RGASPI, 495-277-182, “В отдел кадров ЦК Компартии Испании от члена партии с 1919. год. Файн Арнолд,” April 21, 1938.

${ }^{68}$ RGASPI, 495-277-182, Letter of Filipčev to Edoardo D’Onofrio, April 1, 1938.

${ }^{69}$ RGASPI, 495-277-182, Edoardo D’Onofrio, "Fillipovich Roman (Fein Arnold) Yougoslave", July 19, 1939. 


\section{The Barcelona Conference}

Unable to resolve their ongoing disputes, the Yugoslavs met on March 10, 1938 at the International Brigades Headquarters in Albacete in order to discuss the issue of Maslaric and his conflict with the Returnees. Bogdanov was present as a mediator presiding over only about a dozen Yugoslavs, most directly involved in the dispute. The conference revolved around the same accusations that were circling within the volunteers, pointing out flaws in Maslaric's choice of cadres, and insinuating that he might just prefer good Yugoslav communists dying in the Civil War. Maslaric naturally denied all of these accusations, and claimed the real source of problems were "grandees" who refused to bow to party discipline. ${ }^{70}$ No agreement was reached and no solution was found. As the Yugoslav communists proved unable to sort the dispute, the PCE organized another larger meeting at which they attempted to mediate between the warring factions.

This meeting took place in Barcelona on August $3 .^{71}$ A total of seventeen Yugoslav communists were present. The conference was attended by Edoardo D'Onofrio for the PCE Foreigners Commission and Dimo Dichev as the head of the Slavic volunteers section at the Central Committee of the PCE. Vladimir Ćopić was chosen as the Yugoslav who submitted a report on the situation at the opening of the meeting. In a later memoir, Maslaric insisted that the sole purpose of the conference was to critically evaluate his own work, ${ }^{72}$ which was only partially correct. Moreover, even though he claimed D'Onofrio, Dichev, and Ćopić openly attacked him while supporting the Returnees, ${ }^{73}$ the report shows that this is a gross misrepresentation of facts. In reality, they all took quite a neutral stance. This is particularly interesting in the case of Copić: even though he was the most prominent opponent of Gorkić until 1936, he did not appear to have shared the obsession with unmasking gorkićevci, or the belief that such people were hiding in the ranks of the Temporary Leadership.

Nevertheless, the proceedings do seem to show that a lot of the lowerranking members did perceive the meeting as an opportunity to bring up the perceived errors of Maslaric in front of higher party organs. Almost all of the KPJ members gathered were against Maslarić, and the evaluation of his work was extremely negative. Aside from being called a gorkićevac several times, he was accused of protecting Trotskyists. ${ }^{74}$ Maslarić fought back, accusing the Returnees of cowardice and pointing out their inability to perform tasks they had been ordered to do. ${ }^{75}$ His response, however, was comparatively meek, given the weight

\footnotetext{
${ }^{70}$ RGASPI, 545-2-79, Фурман - Вернер (Dimitrije Stanisavljević), “Собрание в Албасете,” March 10, 1938.

${ }^{71}$ RGASPI, 545-2-79, Н. Николаевич (Milan Kalafatić), “Протокол собрания от 3.VIII. по вопросу взаимоотношений среди тов. из Югославии членов Й.К.П.”, August 3, 1938.

72 Božidar Maslarić, Moskva-Madrid-Moskva: sećanja (Zagreb: Prosvjeta, 1952), 82.

${ }^{73}$ AJ, 790/1 KI, 1939/33, 15.

${ }^{74}$ RGASPI, 545-2-79, Николаевич, "Протокол," 4.

${ }^{75}$ RGASPI, 545-2-79, Николаевич, "Протокол," 3.
} 
of the accusations against him. Vladimir Ćopić, as the main speaker, took a moderate stance, trying to reconcile the two groups. He dismissed the dispute as a personal feud between Maslarić and Filipčev, but claimed that their personal disagreements were nevertheless leading to a formation of factions around them. ${ }^{76}$ According to Maslarić, Ćopić accused him of conducting a poor cadres policy and of favoritism of younger, inexperienced KPJ members over the older ones. ${ }^{77}$ While this is correct, Ćopić did not try to exculpate the old cadres in any way, and also criticized their refusal to go to the frontline. ${ }^{78}$ The most damning accusation actually came from D'Onofrio: he accused Maslarić of essentially overstepping his boundaries, as there were to be no official party representatives in Spain who would report to their parties directly, without the mediation of the PCE. ${ }^{79}$ Gustinčič, who was in charge of censoring the correspondence of all International Brigades staff, denied the accusation and claimed that Maslarić did not try to pose as a party representative in any of his letters. This was untrue: Maslarić had previously informed Tito that there should be no party representatives, but kept acting as one anyway. ${ }^{80}$ It appears that Gustinčič lied to the Comintern representative in order to protect his close associate and fellow ally in the struggle against the Parallel Center and the Returnees.

D'Onofrio further concluded that what is happening among the Yugoslavs was in fact a case of factionalism, although this factionalism was caused by personal, rather than political, disputes. ${ }^{81}$ There is no evidence of any formal creation of groups, but informal links between individuals did in fact amount to a certain kind of factionalism, as various individuals, such as Maslarić and Gustinčič, tried to protect each other and put their joint interests above party rules. The dispute once again brought to the fore the issue of foreign involvement in the factional struggle. In order to gain legitimacy, Filipčev reminded everyone that Bogdanov, as a Comintern representative, also suspected that Maslarić is a gorkićevac. ${ }^{82}$

Overall, however, the three figures of authority present at the meeting seemed uninterested in taking sides. While Maslarić was the target of most of the accusations coming from other Yugoslavs, and therefore saw the meeting as a major defeat, the senior communists criticized Maslarić's cadres' policy and Filipčev's refusal to fight with equal intensity. If D'Onofrio was privately sympathetic to Filipčev and had a personal connection with him, this is not evident from the official proceedings of the Barcelona meeting. ${ }^{83}$ The conclusion, which exists

\footnotetext{
${ }^{76}$ RGASPI, 545-2-79, Николаевич, “Протокол," 7.

${ }^{77}$ AJ, 790/1 KI, 1939/33, 16.

${ }^{78}$ RGASPI, 545-2-79, Николаевич, “Протокол,” 2.

${ }^{79}$ RGASPI, 545-2-79, Николаевич, "Протокол," 5--6.

${ }^{80}$ AJ, 790/1 KI, 1938/12, "Pismo br. 1 za Ota”, February 4, 1938, 2.

${ }^{81}$ RGASPI, 545-2-79, Николаевич, "Протокол”, 5.

82 RGASPI, 545-2-79, Николаевич, "Протокол”, 3.

${ }^{83}$ Moreover, D’Onofrio claims to have used his powers to help Maslarić as well, by protecting him from arrest in March 1938. RGASPI, 545-6-1535, Edoardo D'Onofrio, “Andreief Boris Nicolaef - Yougoslave", October 4, 1939, 5.
} 
in Spanish, but is absent from the Russian-language proceedings, stated that Maslarić and Gustinčič abused their position by continuing to act as party representatives, while Filipčev gathered around himself those who wanted to return to the USSR and the "politically weak." ${ }^{84}$ It states that they are unlikely to end their disputes any time soon, and suggests that they all be sent out of Spain.

These instructions were never actually followed through. The epilogue was far more anti-climactic than the proposed expulsion of a dozen prominent Yugoslav communists. The dispute was not settled in Spain, and thus Maslarić still had to report on it upon his return to Moscow in $1939,{ }^{85}$ while Filipčev was under investigation for over a year in 1939 and $1940 .{ }^{86}$ Indeed, the disagreement could not have been dealt with in Spain: Maslaric was arrested for an unrelated affair soon after the Barcelona meeting, ${ }^{87}$ while Filipčev was hospitalized roughly at the same time, as his condition rapidly worsened. Just a month later, in September, the International Brigades began to evacuate from Spain. Even though the matter was not resolved, the situation was already moving in Tito's favor. He had been summoned to Moscow, and would soon attend the ECCI meeting at which he was tasked with preparing a draft resolution which was to settle the Yugoslav question. ${ }^{88}$ By January 1939, he would be the de facto general secretary. His opponents, Marić and Kusovac, were arrested in Paris by the French police in July 1938 and deported to Spain. ${ }^{89}$ At this point, even Tréand was wary of them, ${ }^{90}$ and therefore Tito successfully isolated them from the Yugoslav volunteers. By the spring of 1939, they were formally expelled from the KPJ.

\section{Conclusion}

While the Yugoslav volunteers in Spain were making a valuable contribution to the struggle of the Spanish left against Francoism, the factional struggles caused by the Great Purge were making their mark behind the lines. Although the dispute only affected a small number of communists behind the lines, it caused enough headaches for the International Brigades leadership and the PCE to intervene on several occasions. Even though they identified the struggle as originating from a personal dispute between Maslarić and Filipčev, it soon took political form, and became another battleground in the war between the Temporary Lead-

${ }^{84}$ RGASPI, 545-6-1519, "Protocolo de la reunion de los cam. yugoslavos convocada por la Seccion de Cuadros Extrangeros del C.C. del PC de Espana, el dia 3 de Agosto de 1938”, 3.

${ }^{85}$ The full report is kept in the Archive of Yugoslavia: AJ, 790/1 KI, 1939/33.

${ }^{86}$ All the documents pertaining to this investigation can be found in RGASPI, 495-277-182, in the personal file of Roman Filipčev.

${ }^{87}$ Maslarić spent the following half a year in prison, until the charges against him were finally dropped in February 1939. AJ, 790/1, KI, 1939/33, 19-21.

${ }^{88}$ RGASPI, 495-18-1112, "Protokoll (A) Nr. 339 der Sitzung des Sekretariats des EKKI vom 17.9.38."

${ }^{89}$ AJ, 507, CK KPJ, 1944/583, „Izjava dr. Radivoja Uvalića Centralnom komitetu Komunističke partije Jugoslavije“, October 15, 1944, 3.

${ }^{90}$ RGASPI, 545-6-1519, Letter of Tréand to Marty, July 26, 1938, and Letter of Marty to Tréand, July $28,1938$. 
ership and the Parallel Center. In reality, neither group really had the authority to implement their desired party line. The situation was made worse by the fact that many of the Yugoslavs were in positions of authority in the International Brigades themselves, but not in the KPJ. This gave them the legitimacy needed to impact the fighters around them, without enabling them to influence the course of the party as a whole. The distinction between party and military authority was always vague. Personalization of responsibility only exacerbated the situation: for example, Gustinčič came to exercise great power over the KPJ without holding any party position, as a consequence of an arbitrary decision to make him in charge of party correspondence. Thus, private disputes, which were at the root of most conflicts among the Yugoslavs, illustrate how easy it was for personal to become political in a time when the Stalinist leadership intentionally insisted on the erasure of the distinction between the two. ${ }^{91}$

The Returnees, as they were dubbed by Tito, posed a significant threat to the authority of the Temporary Leadership. This was not only a consequence of general confusion and active subversion, but also of their extraordinary network of international ties. They enjoyed the support of the Cadres Department through Edoardo D'Onofrio, and the PCE through Maurice Tréand. Moreover, with Anton Ivanov - Bogdanov, Dimitrov's personal emissary, they were just one step away from the most influential man in the Comintern. In spite of Filipčev's significant personal ties, Kusovac, the co-leader of the Paris-based Parallel Center, was equally important. His extensive transnational network, which most likely had its roots in his intelligence activity in the USSR, ${ }^{92}$ made him one of the most influential Yugoslav communists in the Spanish Civil War, even though he did not step foot on Spanish soil until July 1938, and even then not of his own volition. On the other hand, aside from close ties with the Albanian volunteers, considered by the Comintern to have been even more marginal than the Yugoslavs, Gustinčič and Maslarić failed to garner significant support from foreign communists. Thus, the position of the Temporary Leadership in Spain was extremely vulnerable.

Nevertheless, considering the power they had, the efforts of the Parallel Center, and the Returnees as their foot soldiers, were embarrassingly disastrous. Even Kusovac's Albanian contacts were denounced and expelled from the movement. The Albanian factional struggle shows that conflicts within the Comintern should not be observed merely within the confines of national communist parties. The KPJ and the Albanians shared both the fault lines and the outcomes of the dispute; indeed, this was a single factional struggle within two national sections of the Comintern. It was a consequence of Yugoslav jurisdic-

\footnotetext{
${ }^{91}$ An excellent portrayal of this process, and an argument in favor of such an interpretation, is shown on the case study of the Hungarian communist Ludwig Magyar in William J. Chase, Enemies within the Gates? The Comintern and Stalinist Repression, 1934-1939 (New Haven and London: Yale University Press, 2001), 51-101.

92 AJ, 507 CK KPJ - Emigracija, I/29, Kristina Kusovac, „Centralnom komitetu KP Jugoslavije, preko druga Veljka Milutinovića“, January 17, 1945, 1.
} 
tion over Albanian communists, which still remains largely unexplored, but appears to have been significant for the internal affairs of both parties. Moreover, it appears that broader power dynamics within the Comintern impacted them as well, and these should be a future subject of academic inquiry.

The Parallel Center was also not too successful in terms of extending its influence in Spain. Over the course of the factional struggle, the Returnees never attempted to agitate among the volunteers and expand their following. This was probably because such a move would have been seen as sowing dissent and therefore subverting the war effort. They were mostly people who had spent at least a decade in the USSR and had fully internalized the Bolshevik ethos with its emphasis on party discipline. They simply doubted the credibility of the Temporary Leadership due to its links with (or their belonging to) the group of gorkicevci and wanted to wait for the Comintern to resolve the situation before taking action. Such an attitude nevertheless led to them being described as defeatists and liquidators who subverted the cause of the Spanish people.

The same could not be said of the volunteers loyal to the Temporary Leadership, many of whom distinguished themselves in the field of battle with their bravery and skill. ${ }^{93}$ Moreover, some of the personal ties of Kusovac had proven to be a liability, as his closest Albanian comrade became the most prominent Albanian outcast and "Trotskyist." These facts were much more convincing to the Comintern than implausible claims that the Temporary Leadership was somehow secretly sabotaging the Republican war effort by asking the soldiers to actually fight. This, however, was just part of the case that Tito was building against Kusovac and Maric in the struggle for leadership over the KPJ. Ultimately, the struggle was resolved outside of Spain, as Tito succeeded winning the trust of Moscow, but Marić and Kusovac didn't. The Spanish case, as well as the overall factional struggle, show that Tito's victory lay in convincing the Comintern that his political line was more correct and efficient than those applied by his opponents. Connections and backdoor schemings, while important, did not play a primary role. If good connections mattered to the Comintern more than policy, a candidate of the Parallel Center would have become general secretary. Instead, Tito took over and began asserting control over the party. The Returnees themselves were treated quite lightly: as their activity remained a largely internal matter confined to about a dozen people, the resolution of the question of the leadership of the KPJ in 1939 did not lead to their expulsion and was overall less dramatic than the cases of their informal superiors, Marić and Kusovac. Nevertheless, most of the Returnees who survived the war were swept away in the purges following the Tito-Stalin split in 1948, showing that the fault lines which the Great Purge left in its wake still haunted the party even in the postwar period.

\footnotetext{
93 They were some of the most distinguished Yugoslav Spanish Civil War fighters, such as Peko Dapčević, Veljko Vlahović, Mate Vidaković, and Aleš Bebler.
} 


\section{REFERENCES}

- Banac, Ivo (ed.). The Diary of Georgi Dimitrov 1933-1949. New Haven: Yale University Press, 2003.

- Banac, Ivo. With Stalin against Tito: Cominformist Splits in Yugoslav Communism. Ithaca, NY: Cornell University Press, 1988.

- Beevor, Antony. The Battle for Spain: The Spanish Civil War 1936-1939. London: Weidenfeld \& Nicolson, 2006.

- Begolli, Mithat Q. Kryezinjtë e Gjakovës. New York: Association “Libri”, 2012.

- Belić, Stevan. Na bojnim poljima Španije. Beograd: Narodna armija, 1970.

- Bondarev, Nikita. Misterija Tito: moskovske godine. Beograd: Čigoja štampa, 2013.

- Broz Tito, Josip. Sabrana djela, tom III. Beograd: Komunist, 1981.

- Broz Tito, Josip. Sabrana djela, tom IV. Beograd: Komunist, 1981.

- Biscione, Francesco M. Dizionario Biografico degli Italiani, vol. 41, s.v. “D'ONOFRIO, Edoardo.” Rome: Istituto dell'Enciclopedia Italiana, 1992. http://www.treccani.it/enciclopedia/edoardo-d-onofrio_(DizionarioBiografico)/ (accessed September 3, 2017).

- Cenčić, Venceslav. Enigma Kopinič, tom I. Beograd: Rad, 1983.

- Chase, William J. Enemies Within the Gates? The Comintern and Stalinist Repression, 1934-1939. New Haven and London: Yale University Press, 2001.

- Čolaković, Rodoljub. Kazivanje o jednom pokolenju, tom III. Sarajevo: Svjetlost, 1972.

- Dedijer, Vladimir. Novi prilozi za biografiju Josipa Broza Tita, tom II. Zagreb: Mladost, 1981.

- Goldstein Slavko, and Ivo Goldstein. Tito. Zagreb: Profil, 2015.

- Kapor, Čedo. Španija 1936-1939, vols. 1 to 5. Beograd: Vojnoizdavački zavod, 1971.

- Lazitch Branko, and Milorad M. Drachkovitch. Biographical Dictionary of the Comintern. Stanford: The Hoover Institution Press, 1986.

- Maslarić, Božidar. Moskva-Madrid-Moskva: sećanja. Zagreb: Prosvjeta, 1952.

- Nikolić, Kosta. Mit o partizanskom jugoslovenstvu. Beograd: Zavod za udžbenike, 2015.

- Očak, Ivan. Gorkić: život, rad i pogibija. Zagreb: Globus, 1988.

- Očak, Ivan. Vojnik revolucije: Život i rad Vladimira Ćopića. Zagreb: Spektar, 1980.

- Oren, Nissan. Bulgarian Communism: The Road to Power 1934-1944. New York: Columbia University Press, 1971.

- Pavlaković, Vjeran. Yugoslav Volunteers in the Spanish Civil War. Beograd: Rosa Luxemburg Stiftung, 2016.

- Pirjevec, Jože. Tito i drugovi, tom I. Beograd: Laguna, 2013.

- Radanović, Milan. „Jugoslovenski interbrigadisti pred Kontrolnom komisijom CK KPJ 1945-1949“. Bachelor's thesis, University of Beograd, 2016.

- Schwartz, Stephen. “'Enverists' and 'Titoists' - Communism and Islam in Albania and Kosova, 1941-99: From the Partisan Movement of the Second 
World War to the Kosova Liberation War." Journal of Communist Studies and Transition Politics, 25, 1, (2009), 48-72.

- Simić, Pero. Tito: svetac u magli. Beograd: Službeni list SCG, 2005.

- Swain, Geoffrey. Tito: A Biography. New York: I. B. Tauris, 2011.

- Vujošević, Ubavka. „Poslednja autobiografija Milana Gorkića, sekretara CK KPJ." Istorija 20. veka, br. 1, (1997), 107-128.

- Vukliš, Vladan. Sjećanje na Španiju: Španski građanski rat u jugoslovenskoj istoriografiji i memoaristici 1945-1991. Banja Luka: Arhiv Republike Srpske, 2013.

\author{
MA STEFAN GUŽVICA, PhD Candidate \\ University of Regensburg \\ Regensburg, Germany \\ guzvica.stefan@gmail.com
}

\title{
THE SPANISH INQUISITION: FACTIONAL STRUGGLES AMONG THE YUGOSLAV INTERBRIGADISTAS
}

\begin{abstract}
Summary
This article examines the factional struggle of the Yugoslav International Brigade volunteers in the Spanish Civil War, which was a subset of a broader fight for power inside the Communist Party of Yugoslavia between 1937 and 1939. Following the arrest of the general secretary Milan Gorkic by the NKVD, several individuals attempted to fill the power vacuum and assume a leadership post. The conflict quickly spread among the Yugoslavs in Spain, as many of them encountered the warring factions on their way through Paris or behind the frontlines. Two strongest groups, the Temporary Leadership led by Josip Broz Tito and the Parallel Center led by Labud Kusovac and Ivo Marić, were particularly influential, and thus their conflict spilled over into Spain. Nevertheless, the dispute between the volunteers in Spain predated the Paris-based leadership contest. Those who, even before Gorkić's arrest, wanted to leave the International Brigades for various reasons, found their allies in the Parallel Center. The Parallel Center believed that Gorkić's alleged espionage puts into question the legitimacy of the entire top of the party hierarchy. Their allies in Spain, dubbed "the Returnees," believed that this, by extension, casts doubt on the very necessity of fighting in the Spanish Civil War. The Temporary Leadership, on the other hand, continued working with individuals who were close to Gorkić, most likely due to a mere attempt to continue with business as usual. However, this was interpreted by their rivals as an endorsement of potentially traitorous elements.

The factional struggle often entangled the personal and the political, making the two virtually indistinguishable. Tito's main enforcer of the party line in Spain, Božidar Maslarić, had a personal conflict with Roman Filipčev, the unofficial leader of the Returnees. Both groups avoided extending the scope of the struggle, with no more than two dozen people involved in total. The Re-
\end{abstract}


turness, however, posed a significant threat to Maslarić's leadership because of their vast network of transnational ties, which included prominent French, Italian, and Bulgarian communists. They helped Filipčev sabotage Maslarić's attempts at establishing authority in the International Brigades. On top of this, the Albanian communists, who were effectively in the custody of the KPJ, became involved. Their dispute was not an unrelated conflict, but part of a broader power struggle which transcended national party lines.

The division between the two groups of Yugoslav communists was so profound that the representatives of the Spanish Communist Party unsuccessfully attempted to help them mend their relations twice during the course of 1938 . With the retreat of the International Brigades from Spain, the conflict was never fully resolved. However, it showed the international scope of the Yugoslav factional struggle, which was far from being a purely internal party affair. Moreover, the struggle in Spain showed that, in order to win favor from the Comintern, concrete policy proposals and their successful implementation were more significant than extensive international political and intelligence networks. The Temporary Leadership offered a convincing plan for dealing with the crisis of the party, both in Spain and beyond, which prompted the Comintern to eventually make Tito the acting general secretary of the KPJ.

KEYWORDS: Communist Party of Yugoslavia, Spanish Civil War, Comintern, Josip Broz Tito, International Brigades 